\title{
Exploration on cultivation path of innovative and entrepreneurial talents in fishery technology
}

\author{
Xiaojiang Chen ${ }^{1}$, Quan Wang ${ }^{2, *}$ \\ 1, 2 Jiangsu Agri-animal Husbandry Vocational College, Taizhou City, Jiangsu Province, China \\ *Corresponding author: email: cq_cxj@126.com
}

Keywords: Innovative and entrepreneurial; Talents, fishery technology

\begin{abstract}
In order to explore the cultivation path of innovative and entrepreneurial talents in fishery technology, this paper discusses the reform of talents cultivation mode to solve the problem of the disconnection between talents cultivation and enterprise demand, the development of innovative and entrepreneurial courses, the consolidation of innovative and entrepreneurial talents cultivation foundation, and the integration of innovative and entrepreneurial education teaching into talents cultivation and quality education planning. Through these measures, the cultivation of students' innovative awareness and entrepreneurial ability has been strengthened and the quality of personnel training has been improved.
\end{abstract}

\section{Introduction}

According to the relevant documents of the Chinese government ${ }^{[1-3]}$ and previous related studies ${ }^{[4,5]}$, Centering on the cultivation goal of high-quality technical skills talents in aquaculture industry, the school-enterprise joint cultivation of students and the deep integration, the third-order ability of " cognitive specialty, cognitive industry and cognitive employment" is constructed in turn. with the cultivation of professional post ability as the main line and the combination of work and study as the entry point, the professional environment resources are introduced into the teaching process, with the evaluation of professional ability as the core. the talent cultivation mode of " synchronous learning and production cycle, school-enterprise joint cultivation" for aquaculture technology specialty is formed. the mode takes the production process of the enterprise as the main line and the requirements of the enterprise personnel as the standard. during the critical period of fishery production, the students participate in the production practice of related fishing enterprises and learn technical theoretical knowledge at the same time.

\section{Innovate the personnel training mode to solve the problem that personnel training is out of line with the needs of enterprises.}

Closely linked to the core competencies of the professional posts of this professional group, design teaching content, design a project-based curriculum system, rely on the platform cooperation mechanism, make use of production and training bases inside and outside the school to realize the synchronization of professional teaching and fishery production, complete connection of teaching content and post requirements, seamless connection of professional skills and post skills, and innovate and practice the personnel training mode of " simultaneous teaching of fishery and school-enterprise education".

"Simultaneous teaching and fishing" enables course teaching activities to be completed in real production activities, which can effectively stimulate students' learning enthusiasm and improve learning effect. "School - enterprise co-education" closely follows the mainstream technology and cutting-edge knowledge of the industry, effectively improving students' working ability in employment positions. students can directly understand the situation of the industry, enterprises and jobs in advance, making their professional thoughts more stable and their personal positioning more accurate. 
It has solved the demand for talents for the rapid development of aquatic products industry and the transformation and upgrading of enterprises, especially for talents with high professional quality and stable professional thoughts. however, students trained under the traditional training mode often have low professional skills, their personal expectations are divorced from the needs of enterprises, and job-hopping frequently occurs, which is not conducive to the development of the industry.

\section{Develop innovative entrepreneurship curriculum groups and consolidate the foundation for training innovative entrepreneurship talents}

\subsection{Innovation of professional curriculum module}

In order to cultivate students' innovative and entrepreneurial awareness imperceptibly in professional teaching, the school has made it clear that innovative and entrepreneurial education is the core idea of professional education and has set up innovative courses in the teaching plan. this part of innovative courses is not separated from professional education, and the content and teaching methods of the courses reflect innovative requirements. taking this as an entry point, it requires students to not only learn professional knowledge, but also actively explore the forefront and hot issues in this major. the aim is to enable students to master relevant research methods in this field, encourage students to find problems, improve their ability to analyze and solve problems.

\subsection{Innovation and entrepreneurship elective course module}

Apart from the innovative courses in professional teaching, offering innovative entrepreneurship education elective courses, covering three major categories of courses: theoretical, practical and employment, is not only the need to broaden students' knowledge and improve their innovative and entrepreneurial abilities, but also provides a platform for students to perfect their own knowledge structure. Innovative provisions have been made in curriculum content, teaching methods, examination evaluation, etc. school and enterprise jointly arrange guidance teachers, update teaching content in real time, informatization lesson plan design, pay attention to the innovation and interactivity of the curriculum, and emphasize the close combination with practice.

\subsection{Entrepreneurship training course and certification module}

The introduction of SIYB (start and improve your business) entrepreneurship training and KAB (know about business) training aimed at improving students' entrepreneurship ability, based on innovative entrepreneurship education, increase investment, train teachers, and explore entrepreneurship training modes suitable for the characteristics of higher vocational college students. A complete teaching system of " analysis of training needs - design of teaching plan - introduction of courses - selection of students - implementation of training - follow-up support - effect tracking" has been formed. Certification course module. Students can learn relevant practical skills more actively and improve their employment competitiveness through various authoritative certifications. Therefore, courses of industry qualification certification and occupation qualification certification are offered to meet the needs of industry, industry and occupation development. Introducing professional teachers, expanding the scope of training, and providing students with richer choices and consulting services. This kind of training is included in the teaching plan. after obtaining the certification certificate, they will receive corresponding innovation credits.

\subsection{Entrepreneurship practice module}

Through college students' pioneer parks, skill training bases and school-enterprise cooperation, students' real innovation and entrepreneurship platform will be built. Set up an innovative and entrepreneurial project team based on professional projects with interdisciplinary disciplines and complementary grades. in the form of project competitions, through expert evaluation, select valuable project teams to cultivate and invest in entrepreneurial seed funds to support them. Carry out innovative and entrepreneurial training activities to cultivate team cooperation and management capabilities.

Through the "front shop and back factory", the problem of insufficient innovation and 
entrepreneurship ability is solved. Based on the principle of student - oriented, with innovative and entrepreneurial education as the matching point, the school should establish a channel for communication between schools and enterprises so as to provide a good practice platform for college students, establish a team of entrepreneurs to guide teachers, and reserve talents for the development of enterprises at the same time. Take the on-campus college students' entrepreneurship demonstration stores such as the " sailing aquarium", the off-campus cooperative enterprise direct store as the "front store" and the on-campus aquatic product training base and off-campus enterprise as the " back field". Students in grade one and grade two carry out various special skills and practical training of innovation and entrepreneurship in the school, while students in grade three carry out practical training of innovation and entrepreneurship outside the school during the internship stage. Promote the incubation and implementation of entrepreneurial projects.

\section{Innovative entrepreneurship education and teaching should be incorporated into personnel training and quality education planning.}

The implementation of extra-curricular innovative credit system requires students to take credit for scientific research and training and innovative and entrepreneurial activities. social practice, special lectures, academic reports and other required links are linked to academic degrees, scholarship evaluation and merit promotion, making them important indicators in the evaluation system of students' comprehensive quality. By increasing credits for entrepreneurship education, students can be encouraged to actively participate in research-based learning and innovative practice. this is an important measure to cultivate innovative entrepreneurship talents in schools. According to the characteristics of students' specialties, the credit proportion is classified and set. according to the different specialties, students can focus on the ways and contents of obtaining credits. according to their own learning characteristics and growth needs, students can obtain credits from various ways such as innovative entrepreneurship education courses, subject competitions, research studies, experimental research, academic reports, entrepreneurial practices, school-enterprise cooperation, certification training, learning results, production design, compilation of foreign language materials, invention and production.

To establish a guidance system for classified guidance and form a guidance system for innovation and entrepreneurship. With the continuous development of credit system, the school must establish a student-oriented personality guidance system. The school has established an academic tutorial system and an entrepreneurship tutorial system to guide students in autonomous learning, scientific research and innovation, and entrepreneurial practice. In the training mode of innovative entrepreneurial talents, academic instructors and entrepreneurial instructors play an irreplaceable role.

Implement the academic tutorial system. Select outstanding teachers as academic instructors and business instructors and give them corresponding treatment. Academic tutors not only provide comprehensive guidance in the fields of students' courses selection, professional learning, academic research, life planning and other academic fields, but also give personalized guidance to students according to their individual characteristics, so that students can fully develop their personality, tap and show their inherent potential in innovative and entrepreneurial learning and practice, thus cultivating students' habits and abilities of autonomous learning and research-based learning, and realizing individualized teaching and personality cultivation. The entrepreneurial mentor closely centers on various problems of students in entrepreneurial practice and conducts case-based guidance so that students can gradually master the ideas and entrepreneurial skills acquired from solving practical problems.

In the construction of innovative and entrepreneurial talents training mode, the school should incorporate the requirements of innovative and entrepreneurial talents training indicators into the school's evaluation index system, and fully reflect the requirements of innovation and entrepreneurship in evaluation, evaluation and management. Examine students' innovative ability from the level and effect of participation. 


\section{Promotion and application effect}

Since the research and application of achievements were carried out in 2010, Jiangsu vocational college of agriculture, animal husbandry and science and technology, while carrying out its own practice, has achieved rich results by promoting and applying it to brother colleges and universities inside and outside the province through platforms such as China's modern fishery vocational education group and national training institutions for backbone teachers of freshwater fishery specialty in higher vocational schools.

\subsection{The quality of personnel training significantly improved}

Since the college cooperated with MYCOS, an educational evaluation institution, in 2012, the annual report on social needs and training quality shows that the employment quality of graduates majoring in fishery is among the highest among similar majors. Enterprise evaluation students generally have the spirit of being able to bear hardships and stand hard work. they are more practical, have strong practical skills, and have innovative working methods. In 2012 - 2013, the college was awarded the "top 50 universities with typical employment experience for national graduates" by the Ministry of education. in 2014, it was awarded the " national vocational college employment competitiveness demonstration school" by the joint conference of the China youth daily and the national vocational college publicity minister (a total of 30 universities in China).

\subsection{Students' practical ability of innovation and entrepreneurship is continuously improved}

Students majoring in aquaculture technology in the college have continuously improved their practical ability of innovation and entrepreneurship. students have won many awards in innovation and entrepreneurship competitions above the municipal level. In 2015, the work "a leech attached bed" won the first prize of the 7th Jiangsu province vocational education innovation competition. In 2016, "a multifunctional aquarium filter device" won the first prize of the 27th Jiangsu province youth science and technology innovation competition. In 2016, the animal husbandry and leeching industry won the first prize at the provincial level in the fifth Jiangsu province university students' innovation and entrepreneurship competition. The 2016 student landscaping works won the second prize in the final of the 3rd aquarium landscaping skills competition for college students nationwide. The 2017 work "shrimp automatic screening machine" won the first prize in the 28th Jiangsu province youth science and technology innovation competition, " talkative self-entering folding trap cage" and " family aquarium landscaping design" won the second prize. the 2017 " intelligent waterscape" project won the first prize in Jiangsu division of the internet plus national college students' innovation and entrepreneurship competition. the school was successively named " top 50 national colleges' innovation and entrepreneurship" and " top 50 national higher vocational colleges' innovation and entrepreneurship" by the Ministry of education and the China youth daily in 2016.

\subsection{Professional social influence continues to increase}

Through the practical application of this achievement, the school's achievements in running aquaculture technology specialty continuously emerge, and the social influence continues to increase. In 2013, the college undertook the training project of national " domestic training of freshwater aquaculture technology" for professional backbone teachers in higher vocational schools. In 2015, the college became the governing unit of China's modern fishery vocational education group. In 2015, the college undertook the work of formulating the internship standards for aquaculture technology majors in national vocational colleges. In 2016, the aquaculture technology specialty was selected by the China education international exchange association as the Chinese project cooperation specialty of " joint training of millions of high-end skilled and applied talents" to lead the construction and development of aquaculture technology and related specialties in higher vocational colleges nationwide.

\subsection{The school-enterprise cooperation continues and advances in depth}

More than $70 \%$ of students go to cooperative enterprises for employment after studying " order 
class" and " modern apprenticeship class" every year. the enterprises continuously obtain excellent talents, attracting leading enterprises in Tongwei Group Company, Haida Group Company, Dabei nong Group Company and other industries to continue to cooperate in running classes, thus forming a long-term mechanism for school-enterprise cooperation. The number of research and development projects and total funding for school-enterprise cooperation have continued to grow. school-enterprise cooperation is advancing in depth and the results of cooperation benefit both sides.

\section{Summary}

A series of measures have significantly improved students' professional ability, innovative awareness and entrepreneurial ability. Establish a guarantee mechanism for innovation and entrepreneurship that "leads, promotes, helps, and helps". "lead" refers to the guidance of innovation and entrepreneurship awareness. Through the reform of the curriculum system, arrange relevant guidance courses on innovation and entrepreneurship, academic lectures, hold entrepreneurship salons and other activities, broaden students' vision, enhance students' desire, stimulate students' innovative thinking, and solve the problem of thinking afraid to start a business. " promotion" refers to the promotion of competitions and encourages students to actively participate in various national, provincial and municipal competitions for entrepreneurial plans, career planning competitions, scientific and technological inventions and other competitions, so as to create an entrepreneurial atmosphere, cultivate students' competition, innovation, risk and team awareness, and lay a good foundation for entrepreneurship. " help" refers to helping to build a platform, taking innovative and entrepreneurial training programs, scientific research projects, professional associations and other carriers of college students, and taking " open laboratory", " academic mentor", " enterprise mentor" and " party member docking" and other systems as guarantees, to give students guidance and help from the technical level; " help" means financial support, which provides financial support for projects with entrepreneurial intentions and high feasibility and lowers the threshold of entrepreneurship.

Through these measures, Jiangsu vocational college of agriculture, animal husbandry and science and technology has strengthened the cultivation of students' innovative awareness and entrepreneurial ability, improved the quality of personnel training, and attracted famous enterprises from TongWei Group Company, DaBeiNong Group Company, Beijing ShengTaier Group Company and other industries to attend school classes. students' innovative and entrepreneurial ability has been improved, the quality of personnel training and the satisfaction of graduates' enterprises have obviously improved. in succession, more than 4500 professional talents have been trained for the construction of modern fisheries, and aquaculture technology has become the most popular major in the school.

\section{Acknowledgements}

This research was financially supported by Qing Lan Project of Jiangsu Province and Jiangsu Agri-animal Husbandry Vocational College, Social science project (Grant No. SKYB1715). It was also supported by China Vocational and technical education society, 2017-2018, teaching reform and textbook construction project (Grant No. 1710452), and project entrusted by the Vocational Education and Adult Education Department of the Ministry of Education (Grant No. 2018RCXQ01).

\section{References}

[1] China Government. The opinion of Central Committee of the Communist Party and the State Council of China on the implementation of the strategy of Rural Revitalization[J]. Chinese farmers' cooperative, 2018 (03): 7-16.

[2] China Government. Construction plan of modern vocational education system (2014-2020 years) 
[J]. Professional technology, 2014 (8).

[3] China Government. The Ministry of Agriculture issued the thirteenth five-year plan for national fisheries development [J]. Fisheries Science \& Technology Information, 2017 (2) :106-107

[4] Chen X, Sun Q. An Analysis of How to Offer the Vocational Guidance by Internet in China[C]// International Conference on Management, Education and Social Science. 2017.

[5] Chen X, Xiong L, Sun Q. Research and Practice on Innovation and Entrepreneurship Education System in Vocational Colleges[C]// International Conference on Management, Education and Social Science. 2017. 